\title{
Research on the Impact of Human capital on the Transformation and Upgrading of China's Industrial Structure from the Perspective of Low Carbon Development
}

\author{
GaoYiwen $^{1 *}$ \\ ${ }^{1}$ School of economics and management, Beijing Jiaotong University, Haidian, Beijing, China
}

\begin{abstract}
From the perspective of low-carbon, this paper analyzes the impact of human capital on the transformation and upgrading of China's industrial structure. Firstly, it combs the relevant literature, then theoretically analyzes the mechanism of human capital on the transformation and upgrading of China's industrial structure, and then selects the energy consumption data of 30 provinces, autonomous regions, and municipalities (excluding Tibet, Hong Kong, Macao, and Taiwan) from 2006 to 2016 Human capital data, using panel data analysis for empirical test. The results show that human capital has a positive effect on the low-carbon transformation and upgrading of industrial structure, but there are some differences in the effect on the whole country and different regions in the East, middle and West. Finally, from the perspective of the government, enterprises, schools and individuals, this paper puts forward some countermeasures and suggestions, such as responding to the economic transformation and low-carbon economy policies, strengthening human capital investment, and accelerating the cultivation of low-carbon talents.
\end{abstract}

\section{Page layout}

At present, global environmental problems are increasingly prominent. China's environmental problems cannot be underestimated. According to statistics, China's carbon dioxide and sulphur dioxide emissions have far exceeded those of other countries, and the environmental carrying capacity of most regions has reached or exceeded the upper limit ${ }^{[1]}$. At present, China pays more and more attention to the development of low-carbon economy. Low carbon economy has become an important way to achieve sustainable and healthy development of China's economy. As an important driving force of green and low-carbon production, human capital plays an important role in enterprise value creation, technological innovation, and carbon emission reduction under the promotion of knowledge economy. On the one hand, human capital promotes the progress of low-carbon technology, on the other hand, it improves the speed of new technology application in various industrial sectors, and then transform the traditional high-carbon industry and promote the development of emerging low-carbon industry, promote the upgrading of industrial structure, realize the low-carbon industrial structure.

\section{Literature review}

In the case of lack of resources and environmental pollution, China urgently needs to change the current high-energy consumption mode of economic development. In fact, the transformation of economic development mode requires the optimization and upgrading of industrial structure. In the current lowcarbon background, the development of industrial structure towards low-carbon direction is the key.

The theory of human capital gradually formed in 1960s. After that, economists at home and abroad introduced it as an influencing factor into the research of industrial structure, and they generally believed that the effect of industrial transformation and promotion is inseparable from the level of human capital. Ciccone and Papaioannou (2009) found that the higher the education level of residents in a country or region, the better the development of knowledge intensive industries, and the faster the human capital accumulates, the more advanced the industrial structure of the country will be ${ }^{[2]}$. Bodman (2013) research holds that human capital promotes the optimization and upgrading of industrial structure by developing new processes and creating new products through the role of science and technology innovation ${ }^{[3]}$. Chen Jian (2011) found that the more reasonable the allocation of human capital in the region, the more healthy the development of industrial clusters in the region, and then the region's economy will grow steadily in a sustained and healthy direction ${ }^{[4]}$.

In recent years, with the increasing attention of the relationship between resource environment and economic development, domestic and foreign scholars began to study the relationship between human capital and low-carbon economy. Che Weiping and Su Rui (2014) analysed the impact of human capital build-up on

\footnotetext{
* Corresponding author: 19120552@bjtu.edu.cn
} 
low-carbon economy, and thought that human capital can bring technical advancement, and the low-carbon technology directly affects the low-carbon economy ${ }^{[5]}$. Qin Tianru et al. (2018) studied the role of human capital in green low-carbon innovation in industrial enterprises from a more micro perspective. It was found that human capital has a positive impact on the efficiency of green low carbon innovation in industrial enterprises ${ }^{[6]}$.

Through the above findings: many researchers have done great deal of study on the driving effect of human capital on industrial transformation and upgrading for a long time, but most of the existing literature on lowcarbon upgrading has not made in-depth analysis of the role of human capital in it, just as a little explanation of the control variable, it cannot fully explain the mechanism of human capital, Some literature also only analysed from the micro perspective, and the driving effect of low carbon upgrading has not been paid enough attention to. In view of this, based on the theoretical model of the driving effect of human capital, this paper makes an empirical study to explore its possible impact and puts forward relevant countermeasures and suggestions.

\section{Theoretical analysis}

For low-carbon economy, human capital is an important non-material driving factor. It puts forward an immense influence on the transformation of industrial structure towards low carbon, which is mainly realized through direct and indirect channels.

\subsection{Direct influence}

In the context of low-carbon, the direct effect of human capital is realized as a factor of production. Under this influence mechanism, human capital directly affects the industrial structure through its substitution effect, internal effect, and external effect.

Substitution effect means that human capital can directly and indirectly replace energy input by virtue of accumulated knowledge, and overcome the shortage of natural resources, material capital and "original labour". The promotion and structural optimization of human capital as an element itself will promote the high carbon emission industry, change the material capital input such as energy, and promote the low-carbon of high carbon industry.

Internal effect refers to the effect of increasing the stock of individual human capital through human capital investment, bringing about the improvement of individual productivity. Human capital generated by education investment spills over in the form of internal effect, resulting in knowledge innovation. The more knowledge and skills people have, the higher productivity and creativity they have.

External effect refers to the knowledge and capability formed by human capital investment, which will increase the production efficiency of people around and the productivity of material capital. The internal effect promotes agglomeration, while the agglomeration of human capital enlarges its external effect. Human capital agglomeration improves the green production efficiency of industry and greatly promotes the development of low-carbon industry through the re allocation of input factors and technological reform and innovation.

\subsection{Indirect influence}

The indirect effect of human capital on the low-carbon transformation and promotion of industrial structure is that human capital is regarded as the input factor of other activities, and indirectly affects its transformation and upgrading towards the low-carbon direction by influencing other intermediaries. Previous studies have shown that low-carbon transformation and upgrading of industrial structure depends on technological progress and changes in demand structure, and human capital is an important factor affecting these factors. Human capital is the source of innovation and the backbone of low-carbon technological progress. The new economic growth theory also believes that human capital is not only a factor of production, but also a source of technological progress. It proposes that economic growth in the new era is driven by science and technology, and human capital cannot only have a direct effect on the improvement of energy efficiency, it also promotes the creation and application of energy-saving technology through technology, which indirectly affects energy efficiency. In addition, Keynesian theory holds that demand determines supply, and demand structure determines supply structure. Therefore, the low-carbon demand structure caused by human capital will bring low-carbon supply structure, and then affect the development of low-carbon industry.

Through combing the existing literature and theoretical analysis, we can see that human capital has a positive role in promoting the transformation and upgrading of low-carbon industrial structure. However, the economic development, technical conditions and resource endowment are significantly different from various regions, and there is significant heterogeneity in the level of human capital in different regions, what is the effect of human capital on the low-carbon transformation and upgrading of industrial structure in different regions? In order to further explore this problem, this study puts forward the following research hypotheses:

H1: Human capital has a positive impact on the lowcarbon transformation and upgrading of China's industrial structure.

H2: The effect of human capital on low-carbon transformation and upgrading of industrial structure in different regions of China is different.

\section{Empirical analysis}

\subsection{Model construction}

This paper takes 30 provinces, autonomous regions, and municipalities directly under the central government (excluding Tibet, Hong Kong, Macao, and Taiwan) as 
the research object from 2006 to 2016 to explore the impact of human capital on the transformation and upgrading of industrial structure. The data are from the China Energy Yearbook, China demographic and Employment Statistics Yearbook, China Science and technology statistical yearbook and the statistical yearbook of each province from 2007 to 2017.

The construction model is as follows:

$$
y_{i t}=\alpha_{0}+\beta_{0} l n h_{i t}+\beta_{i} z_{i t}+\varepsilon_{i t}
$$

Where $i$ and $t$ denote region and year, $y_{i t}$ is the lowcarbon level of industrial structure. $\beta_{0}$ is the estimated coefficient of human capital variable, $\beta_{i}$ is the coefficient to be estimated of the control variable. $\operatorname{lnh}_{i t}$ represents the human capital variable, $z_{i t}$ represents control variables, including the level of environmental regulation, industrial structure, and technological innovation, $\varepsilon_{i t i s}$ the disturbance term, $\varepsilon_{i t} \sim\left(0, \sigma_{\varepsilon}^{2}\right)$.

\subsection{Variable description}

Explained variable. Low carbon level of industrial structure. This paper mainly uses the research achievements of Wang Shaohua and Ding Yuejin for reference. The comprehensive evaluation index system of low-carbon level of industrial structure includes lowcarbon output, low-carbon energy consumption and lowcarbon emission.

The core explanatory variable is the level of human capital. Considering the availability of data, this paper uses the years of education to representative the level of human capital.

Because the low-carbon level of industrial structure is not only affected by the level of human capital, but also by regional economy, technology, and other factors, so the control variables are selected. Among them, the level of environmental regulation is expressed by the proportion of investment in pollution control of industrial enterprises in regional GDP; The industrial structure is expressed by the proportion of the output value of the tertiary industry in the regional GDP; The level of scientific and technological innovation is measured by the proportion of social $\mathrm{R} \& \mathrm{D}$ investment in GDP.

\subsection{Cointegration test}

In order to prevent pseudo regression, ADF method was used to test the unit root of the data. The level statistics of some variables do not pass the test. At the significance level of $1 \%$, the first-order difference sequence is stationary, and all variables have the firstorder single integral sequence. It is proved that the data is stable and can be used for empirical research.

In this paper, EG two-step cointegration test, cointegration test results are shown in the table below. Results there is a long-term equilibrium relationship among the variables in the table, and the data has significant stability.
Table 1. Cointegration test of panel data

\begin{tabular}{|c|c|c|}
\hline & Statistic & p-value \\
\hline Modified Dickey-Fuller test & 3.380 & 0.000 \\
\hline Dickey-Fuller test & 1.960 & 0.025 \\
\hline Augmented Dickey-Fuller test & 2.061 & 0.018 \\
\hline $\begin{array}{c}\text { Unadjusted modified Dickey-Fuller } \\
\text { test }\end{array}$ & -3.286 & 0.000 \\
\hline Unadjusted Dickey-Fuller test & -4.453 & 0.000 \\
\hline
\end{tabular}

After the Hausmann test, the chi square distribution value is 319.20 , $\mathrm{P}$ value is 0 . The results show that we should reject the original hypothesis and choose the fixed effect model to study the problem. Therefore, this paper uses fixed effect model for empirical test in panel regression.

\subsection{Empirical results}

Table 2. Estimated results

\begin{tabular}{|c|c|c|c|c|}
\hline & $\begin{array}{l}\text { The whole } \\
\text { country }\end{array}$ & The east & The mid & The west \\
\hline Human Capital & $\begin{array}{c}1.342^{* * *} \\
(0.413)\end{array}$ & $\begin{array}{c}4.067 * * * \\
(0.751)\end{array}$ & $\begin{array}{c}3.501^{* * *} \\
(0.934)\end{array}$ & $\begin{array}{c}2.683^{* * *} \\
(0.934) \\
\end{array}$ \\
\hline $\begin{array}{l}\text { Environmental } \\
\text { Regulation }\end{array}$ & $\begin{array}{l}0.152 * * \\
(0.024)\end{array}$ & $\begin{array}{c}0.084^{* *} \\
(0.037)\end{array}$ & $\begin{array}{c}0.153 * * \\
(0.073)\end{array}$ & $\begin{array}{c}0.083 \\
(0.073)\end{array}$ \\
\hline $\begin{array}{l}\text { Industrial } \\
\text { Structure }\end{array}$ & $\begin{array}{c}0.847 * * * \\
(0.323)\end{array}$ & $\begin{array}{c}0.579 \\
(0.553)\end{array}$ & $\begin{array}{c}4.923 * * * \\
(1.331)\end{array}$ & $\begin{array}{c}0.715 \\
(1.331)\end{array}$ \\
\hline $\begin{array}{l}\text { Technological } \\
\text { Innovation }\end{array}$ & $\begin{array}{c}0.416^{* * *} \\
(0.021)\end{array}$ & $\begin{array}{c}0.666^{* * *} \\
(0.074)\end{array}$ & $\begin{array}{c}0.817 * * * \\
(0.134)\end{array}$ & $\begin{array}{c}0.732 * * * \\
(0.134)\end{array}$ \\
\hline Constant & $\begin{array}{c}-6.798 \\
* * * \\
(0.382)\end{array}$ & $\begin{array}{c}-25.236 \\
* * * \\
(0.957)\end{array}$ & $\begin{array}{l}-20.028 \\
(0.851)\end{array}$ & $\begin{array}{c}-15.307 \\
* * * \\
(0.851)\end{array}$ \\
\hline
\end{tabular}

It can be seen from the table that human capital has a positive effect on the transformation and upgrading of industrial structure under the background of low carbon, but the driving effect of human capital is different in different regions. Therefore, the impact of human capital on low-carbon industrial structure decreases from east to west. It reflects that the level of environmental regulation has passed the 5\% significance level in the eastern and central regions, which shows that it plays a positive role in promoting the low-carbon industrial structure, but the coefficient in the western region is not significant. The coefficient of industrial structure is significantly positive, mainly because the proportion of China's third industry has increased, the industrial structure is more reasonable, and the carbon intensity of the industrial system has decreased. The estimated result of science and technology innovation level has passed the significant level of $1 \%$, which indicates that with the improvement of science and technology level, the industrial structure has also been transformed and upgraded to low carbon.

Table 3. Robustness check

\begin{tabular}{|c|c|c|c|c|}
\hline & $\begin{array}{c}\text { The whole } \\
\text { country }\end{array}$ & The east & The mid & The west \\
\hline Human Capital & $\begin{array}{c}1.252^{* * *}(0 \\
.311)\end{array}$ & $\begin{array}{c}3.457 \\
* * * \\
(0.651)\end{array}$ & $\begin{array}{c}3.001^{* * *} \\
(0.816)\end{array}$ & $\begin{array}{c}2.380 \\
* * * \\
(0.816)\end{array}$ \\
\hline
\end{tabular}




\begin{tabular}{|c|c|c|c|c|}
\hline $\begin{array}{c}\text { Environmental } \\
\text { Regulation }\end{array}$ & $\begin{array}{c}0.051^{* *} \\
(0.024)\end{array}$ & $\begin{array}{c}0.094 * * \\
(0.037)\end{array}$ & $\begin{array}{c}0.178^{* *} \\
(0.073)\end{array}$ & $\begin{array}{c}0.080 \\
(0.073)\end{array}$ \\
\hline $\begin{array}{c}\text { Industrial } \\
\text { Structure }\end{array}$ & $\begin{array}{c}0.854 \\
* * * \\
(0.314)\end{array}$ & $\begin{array}{c}0.578 \\
(0.554)\end{array}$ & $\begin{array}{c}4.976 * * * \\
(1.134)\end{array}$ & $\begin{array}{c}0.610 \\
(1.134)\end{array}$ \\
\hline Technological & $\begin{array}{c}0.216 \\
* * * \\
\text { Innovation }\end{array}$ & $\begin{array}{c}0.676 \\
* * * \\
(0.041)\end{array}$ & $\begin{array}{c}0.816^{* * *} \\
(0.124)\end{array}$ & $\begin{array}{c}0.742 \\
* * * \\
(0.125)\end{array}$ \\
\hline Constant & $\begin{array}{c}-6.893 \\
* * * \\
(0.392)\end{array}$ & $\begin{array}{c}-24.226 \\
* * * \\
(0.946)\end{array}$ & $\begin{array}{c}-21.127 \\
(0.941)\end{array}$ & $\begin{array}{c}-15.348 \\
* * * \\
(0.941)\end{array}$ \\
\hline
\end{tabular}

Starting from the research object, this paper removes the two regions with the highest and lowest level of lowcarbon industrial structure, and regresses the data of other regions. The results show that the significance of each variable is basically consistent with the original model, and the coefficient changes little, which proves the robustness of the model.

\section{Conclusion and suggestion}

Economic development at the cost of environment has posed a great threat to China's sustainable development, and the importance of green and low-carbon development has been put on the agenda. Based on the low-carbon perspective, this paper selects the data of 30 provinces from 2006 to 2016 to establish a panel data model, and analyzes the impact of human capital on the low-carbon transformation and upgrading of China's industrial structure, The results show that: with the improvement of the level of human capital, the lowcarbon level of industrial structure is also on the rise, but from its coefficient, we can get that the driving effect of human capital on the low-carbon level of industrial structure is not very big, which is mainly due to the low quality of China's overall labor force and the low level of human capital. In addition, due to the differences in the level of human capital between the East and the west, the level of human capital in the eastern region is the highest, followed by the central region, and the western region is the lowest. In addition, the level of environmental regulation, industrial structure and technological innovation have a certain impact on the transformation and upgrading of China's industrial structure to low carbon.

On the basic of the above analysis and research conclusions, in order to realize China's low-carbon development path, this paper gives the following countermeasures and suggestions:

For the government, it should pay attention to human capital investment, optimize the allocation of human capital, vigorously promote economic transformation, and advocate low-carbon economy. First, the government should increase investment in education at all levels, improve education infrastructure and improve the quality of human capital; Second, the government should improve the structure of human capital, build a diversified education investment system, establish a perfect human capital market system, and strengthen regional exchanges and cooperation in the field of human capital; Third, the government should strengthen the cultivation of low-carbon education, establish a green and low-carbon professional training and incentive mechanism, encourage enterprises to transform to lowcarbon, and indirectly promote the demand of enterprises for low-carbon talents.

For enterprises, first, they should actively respond to the policies of national economic transformation and low-carbon economy, and upgrade to low-carbon transformation. And then, enterprises should think highly of the skill training of employees, so that the basic employees within the enterprise can meet the requirements of low-carbon transformation and upgrading of industrial structure.

For schools, it is important to keep up with the requirements of the times, strengthen the cultivation of low-carbon talents, establish students' low-carbon concept, establish low-carbon related majors, and cultivate students' innovation ability and practical ability.

For individuals, they should increase their own human capital investment, strengthen the concept of human capital investment, establish scientific human capital values, actively participate in education and training, and improve their cultural level and skill level, to help with China's high-quality development.

\section{References}

1. Ren, X.J., Qin, X.E., Zhang, L.L. (2018) The Influence of Environmental Regulation on the Spatial Evolution of Environmental Pollution. J. Journal of Beijing University of Technology.,20 :18.

2. Ciccone, A., Papaioannou, E. (2009) Human Capital, the Structure of Production and Growth. J. The Review of Economics and Statistics., 91: 66-82.

3. Bodman, P., Le T. (2013) Assessing the Roles that Absorptive Capacity and Economic Distance Play in the Foreign Direct Investment-productivity Growth Nexus. J. Applied Economics., 45 :1027-1039.

4. Chen, J. (2011) Research on Human Capital Influencing Industrial Structure-In the view of Industrial Cluster. J. Science Economy Society., 29: 44-48.

5. Che, W.P., Su, R. (2018) The Impact of the Accumulation of Human Capital on Low-carbon Development. J. Journal of Hebei University., 39: 105-108.

6. Qin, T.R., Kang, L., Liang, W.Q. (2018) Research on Innovation Effect of Regional Human Capital Based on the View of Green Low-Carbon Development_-An Empirical Study of Regional Industrial Enterprises Panel Data in China. J. Human Resources Development of China., 35:107117. 